\title{
Spilt Ink: Aesthetic Globalization and Contemporary Chinese Art
}

\section{Citation}

Gaskell, Ivan. 2012. Spilt ink: Aesthetic globalization and contemporary Chinese art. British Journal of Aesthetics 52(1): 1-16.

\section{Published Version}

doi:10.1093/aesthj/ayr052

\section{Permanent link}

http://nrs.harvard.edu/urn-3:HUL.InstRepos:8360411

\section{Terms of Use}

This article was downloaded from Harvard University's DASH repository, and is made available under the terms and conditions applicable to Other Posted Material, as set forth at http:// nrs.harvard.edu/urn-3:HUL.InstRepos:dash.current.terms-of-use\#LAA

\section{Share Your Story}

The Harvard community has made this article openly available.

Please share how this access benefits you. Submit a story.

\section{Accessibility}


British Journal of Aesthetics 52, 1, 2012

\title{
Spilt Ink Aesthetic Globalization and Contemporary Chinese Art ${ }^{*}$
}

\author{
Ivan Gaskell
}

\begin{abstract}
In response to globalization, is there to be a single, homogeneous set of aesthetic values governing the production and consumption of art? The article focuses on a newcomer to globalized contemporary art, China. It suggests that artworld art (encompassed by the artworld institutions of commerce, museums, and the academy) is far from the only art currently produced. Art beyond the artworld, whether commercial or religious, is important to many people worldwide. It describes four kinds of art currently made in China. Three are artworld art (Modernist, traditional, and avant-garde), one is non-artworld (mass commercial). Connections exist among them. Further, it argues that practices in all four conform to expectations globally that Chinese art of all kinds should exemplify imitation, emulation, and copying. Such conformity entails what Winnie Wong has termed 'staging Chineseness'. The article concludes with an examination of this process in two recent exhibitions before proposing that a proliferation of a variety of values is unavoidable while contemporary artworld practitioners continue to introduce local concerns, and while the self-claimed high status of artworld art is progressively challenged by the vitality worldwide of non-artworld art. While some of these values are resistant to Western globalizing homogenization, others conform to it.
\end{abstract}

1. Although I hope to cast some light on aesthetic globalization, my focus is on one country: China. In recent years, many people outside China have had opportunities to see considerable quantities of contemporary Chinese art. The epicenter of what has become a global phenomenon was the China/Avant-Garde exhibition at the National Art Gallery, Beijing in 1989, co-organized by the critic and art historian Gao Minglu, now chair of the Department of Art History, Sichuan Fine Art Institute. The police closed the exhibition after just four hours. Twenty years and many exhibitions and publications later, police in Beijing prevented Gao and his fellow organizers from hosting two commemorative events scheduled at the same venue in 2009 . The

\footnotetext{
* This article derives from papers given at two symposia in 2011: The State of Aesthetics (Institute of Philosophy, University of London), and Unsettled Boundaries: Philosophy, Art, and Ethics, East/West (Marquette University, Milwaukee, Wisconsin). I should like to thank the organizers and fellow participants for suggestions that led to revisions. I should also like to thank A.W. Eaton, Gao Shiming, and-most especially-Winnie Won Yin Wong. The award of the Beinecke Fellowship at the Sterling and Francine Clark Art Institute, Williamstown, Massachusetts for the fall semester, 2011 enabled me to complete this article. I wish to express my gratitude to the director of the Research and Academic Program at the Clark, Michael Ann Holly, her colleagues, and the other fellows, for unstinting intellectual stimulation and practical support.
} 
Chinese avant-garde artists whose work was to have been shown, and others, had embraced and developed Western contemporary art practices. Solely for convenience, I shall use the term Chinese avant-garde to describe their work and that of others who pursue similar practices.

As recently as 2005, Britta Erickson, curator of the exhibition On the Edge: Contemporary Chinese Artists Encounter the West at the Cantor Arts Center at Stanford University, could claim: 'China's avant-garde artists are doubly marginal. They are marginalized in their own country, and China's art is considered marginal by the international art community'. ${ }^{1}$ We might interpret this claim as no more than a sales pitch appealing to the value of novelty, for by then Chinese avant-garde art was penetrating the entire artworld. (By the artworld I mean the international system of exhibition, collection, commerce, scholarship, and publication centered on galleries, auction houses, museums, biennials, fairs, publishers, websites, art schools, colleges, and universities.) Let us look at auctions. In 2008, Christie's organized its first prestigious evening sales of Chinese contemporary art. At the February, 2010 sale of Chinese contemporary art at Sotheby's, London, all the lots sold, meeting or exceeding their estimates. On April 3, 2011, Sotheby's, Hong Kong offered works from the early years of the Chinese avant-garde-the $1980 \mathrm{~s}$ and early '90s-under the title The Nascence of Avant Garde China. This sale was drawn exclusively from the holdings of a leading collector of Chinese avant-garde art, Belgian industrialist, Guy Ullens. It was hugely successful. For instance, Zhang Xiaogang's oil on canvas triptych, Everlasting Love, painted in 1989 , sold for over $\$ 10,000,000{ }^{2}$ Equally importantly, the sale arguably marked a watershed in the historical conception of the movement. ${ }^{3}$ It now has an internal history of its own.

Beyond the aesthetic and commercial spheres, Chinese avant-garde art has entered Western public consciousness owing to the detention on the very same day as the Ullens saleApril 3, 2011-of the single most famous Chinese avant-garde artist, Ai Weiwei. Ai had come to international prominence largely thanks to his collaboration with the Swiss architecture practice, Herzog \& de Meuron on the Beijing National Stadium for the 2008 Olympic Games. He has long been a critic of corruption in China. For instance, in 2011 he created a work that exploits a Chinese pun. A photographic self-portrait of him jumping naked in mid-air holding a toy alpaca to his groin is accompanied by a caption, 'Grass mud horse covering the middle'. In Mandarin, this can also be enunciated to sound like 'Fuck your mother, the Communist Party Central Committee'. ${ }^{4}$ Wei's detention led to widespread protests internationally. For example, a large sign reading 'Free Ai Weiwei' was installed on the exterior of Tate Modern, London, where between October, 2010 and May, 2011 his huge installation, Sunflower Seeds, comprising innumerable individually hand-painted porcelain trompe l'oeil sunflower seeds, filled the gigantic Turbine Hall. ${ }^{5}$

The meteoric rise of Chinese avant-garde art is a fascinating phenomenon, but it raises a host of questions. I defined the artworld as a complex of Western institutions, but not all art falls within the artworld: far from it. In the first place, there is non-Western art-or however 'art' might be termed in its societies of production; that is, art or its equivalent that has not

\footnotetext{
${ }^{1}$ See http://museum.stanford.edu/news_room/archived_exhibitions_on_the_edge.html (accessed June 3, 2011).

${ }^{2}$ It realized HKD79,060,000 against an upper estimate of HKD30,000,000.

${ }^{3}$ Kyle Chayka, 'Why You Should Care about Sotheby's Ullens Contemporary Chinese Art Sale', Hyperallergic, February 10, 2011: http://hyperallergic.com/18592/sothebys-ullens-sale/ (accessed June 3, 2011).

${ }^{4}$ See, among sources, Linda Leith's blog: http://www.lindaleith.com/posts/2011/04/19/from-yan-liang-aiweiwei-s-disappearance (accessed October 3, 2011).

${ }^{5}$ See http://www.tate.org.uk/modern/exhibitions/unileverseries2010/ (accessed September 29, 2011).
} 
been amalgamated into Western artworld institutions. As yet unappropriated, non-artworld art includes, for example, inexpensively and anonymously produced Indian religious posters and paintings, ${ }^{6}$ and Haitian Vodou artifacts that might find a place in Western anthropology museums - as in the case of the exhibition Vodou: Art and Mysticism from Haiti traveling in Europe between 2007 and 2011-but not yet in art museums, in spite of the aspiring title of the exhibition. ${ }^{7}$ In the West as well as elsewhere, art outside the artworld is a huge phenomenon, commercially, domestically, and devotionally. Just two examples must suffice. Thomas Kinkade claims to be the most collected living American artist, and has trademarked the designation, 'The Painter of Light ${ }^{T M}{ }^{8} .{ }^{8}$ His saccharine landscapes represent mawkish fairy-tale scenes or banal ideals of cosiness, with titles such as Bambi's First Year, Christmas Moonlight, and Make a Wish Cottage. Technically, they are at least superficially accomplished. Kinkade's work is exclusively secular and domestic. However, religion is another context of Western non-artworld art. A vast quantity of Roman Catholic devotional art exists outside the artworld. At the pinnacle is the image of Jesus Christ as the Divine Mercy, produced by the obscure Polish professional artist, Eugeniusz Kasimirowski in 1934 after a vision experienced by the recently canonized Polish nun, Saint Faustina. It is now one of the most revered images in the entire Catholic world, reproductions of it officially bearing the same sacred charge and efficacy as the original in Vilnius, Lithuania. ${ }^{9}$ Art is a major part of many people's lives throughout the world, though not necessarily the art of the artworld..$^{10}$

If these things, and many others, are outside or beyond the artworld, what distinguishes the art that is actually part of it? The artworld has formed around a distinctively Western core. In the West, art practice and art history and theory have existed since the sixteenth century in a mutually reinforcing relationship. ${ }^{11}$ The perception of the Modern as the crescendo of artworld achievement prompted artists and art historians to search for its antecedents, lending retrospective validation to the work of certain nineteenth-century European artists. Picasso's rehabilitation of Ingres at the inception of Cubism early in the twentieth century is a prominent example. Western artists and commentators continue to propose a narrative of progressive change as they address ever-developing issues. In the twentieth century and beyond, these have included the figure-ground dilemma in painting, and the place of the plinth-if any-in sculpture. Practice and discussion occur within the terms of a perceived canonical succession of individual Western artists and movements, exemplified by Afred Barr's celebrated chart of the

\footnotetext{
${ }^{6}$ Available from such websites as Art of Legend India: http://www.artoflegendindia.com (accessed September 29, 2011).

${ }^{7}$ Musée d'ethnographie, Geneva, 2007; Tropenmuseum, Amsterdam, 2008; Världskulturmuseet, Gothenburg, 2009; Ethnologisches Museum, Berlin, 2010; Überseemuseum, Bremen, 2011.

${ }^{8}$ See http://www.thomaskinkadeasheville.com/kinkade.htm (accessed September 29, 2011).

${ }^{9}$ See Ivan Gaskell, 'Jesus Christ as the Divine Mercy by Eugeniusz Kazimirowski: The Most Influential Polish Painting of the Twentieth Century?', Ars: Journal of the Institute of Art History of Slovak Academy of Sciences 42, 1, 2009, pp. 81-91.

${ }^{10}$ Various aspects of art beyond the artworld were addressed in the session, 'Beyond Art' that I organized and chaired at the annual meeting of the College Art Association, New York City, February 11, 2011. I am grateful to the participants who gave papers: Janice Baker, David Carrier, Gabrielle Decamous, Pradeep Dhillon, Joachim Pissarro, and Jacob Wamberg.

${ }^{11}$ Giorgio Vasari, whose Le vite de' più eccellenti pittori, scultori e architettori (1550; second edition, 1568; called in English, Lives of the Artists) is the acknowledged founding text of art history, was not only an artists' biographer, but also a painter and art theorist.
} 
succession of, and relationships among, abstract art 'isms.' ${ }^{12}$ In consequence, contemporary artworld art has predominantly become little more than a way of 'doing theory' about art. It rarely escapes self-reflectivity and solipsism, and only occasionally exhibits aboutness-Arthur Danto's term ${ }^{13}$-concerning anything other than itself. This is clearly a Western phenomenon, exemplified by work by conceptual artists such as Lawrence Weiner; but, like so much else, it has been and continues to be shaped by globalization as artists from an increasing number of parts of the world participate in a continuing contemporary art discourse. This self-reflective behavior had previously been largely confined to Europe and North America, with outliers in South America. Now these concerns-and, of course, others-are being addressed by artists throughout the world for a system of exhibition and commerce that is fully global. That system is in part coordinated through the Web, as the website oneartworld.com exemplifies through which the works of artists such as Beijing and Hong Kong based Yan Lei are available. ${ }^{14}$ Yet physical exhibition remains significant: Yan's work is shown in commercial galleries in Asia, Europe, and North America. ${ }^{15}$

Intersecting with Modernist concerns in globalized art practice is the continuing incorporation of two kinds of things: earlier local products of the predecessors of contemporary practitioners worldwide into the artworld; and things from previously non-artworld locations that have served as sources of inspiration for artworld artists from the early twentieth century onwards. Since the early twentieth century, Western artworld artists have sought inspiration in the art of peoples whose products had previously been considered to lie outside the boundaries of art. Man Ray's famous photograph, Black and White (1926) exemplifies this phenomenon, the White model's face contrasted with the shiny black wood of the Baule mask from Côte d'Ivoire. Today, global artworld artists also look to their own local traditions, giving their internationally consumable artworks a recognizably local inflection. The installation begun in 1987 by Xu Bing, $A$ Book from the Sky, comprising hand-printed books and scrolls printed from blocks inscribed with 'false' characters, is a prime example. It was included in the short-lived 1989 China/Avant-Garde exhibition in Beijing. More than any other single work, its showing in Japan and America in 199192, and at the Venice Biennale in 1993, brought Chinese avant-garde art to international public attention.

At present, critics, curators, dealers, artists, and collectors jet from annual fair to biennial to triennial-from Venice to Singapore to São Paolo to Miami Beach to Guangzhao-continent hopping non-stop. The Guggenheim Foundation has opened or has planned museums not only in New York City, but in Bilbao, Berlin, Guadalajara, Rio de Janeiro, and Abu Dhabi. The key question is: Is there to be a single, varied but coherent governing set of values (including aesthetic values) for this artworld to which all elements conform - a global homogeneity representing a triumph of largely Western preoccupations emerging from the experience of modernity-or is there to be a more widely varying, disparate, open-ended array of values reflecting cultural peculiarities not amenable to homogenization? We may eventually see various sets of practices that partake of both, especially as-counter-intuitively-art made within and for the artworld catches up with art made and functioning beyond it.

\footnotetext{
${ }^{12}$ See the chart on the cover of Alfred H. Barr, Jr., Cubism and Abstract Art: Paintings, Sculpture, Constructions, Photography, Architecture, Industrial Art, Theatre, Films, Posters, Typography (New York: Museum of Modern Art, 1936).

${ }^{13}$ Arthur C. Danto, The Transfiguration of the Commonplace: A Philosophy of Art (Cambridge, MA and London: Harvard University Press, 1981).

${ }^{14}$ See http://oneartworld.com/artists/Y/Yan+Lei.html (accessed July 26, 2011).

${ }^{15}$ Beijing, Hong Kong, San Gimignano, Boissy-le-Châtel (near Paris), and New York.
} 
Art made in China is playing a particular role, demonstrating that artists can deal with matters beyond art itself while yet satisfying Western art adjudicators that they are also taking account of purely artworld concerns. For instance, in a well-known photo triptych (in an edition of eight), Dropping a Han Dynasty Urn (1995), Ai Weiwei enacts a performance making explicit his relationship to Western Conceptual art of the 1960s, such as Keith Arnatt's Self-Burial (Television Interference Project), (1969; Tate, London), ${ }^{16}$ while memorably addressing China's equivocal relationship to its deep cultural past. At root, art of this kind from China is a response to cultural encounter between China and elsewhere. Another work by Ai encapsulates ambiguous social critique: Han Dynasty Urn with Coca-Cola Logo (1994). ${ }^{17}$ This is a conflation of a fragment of Chinese deep cultural identity-a two thousand-year-old ceramic vessel-with the symbol of American global capitalism. Does it imply a polluting, neo-colonial affront to China, or is it a token of the successful absorption of foreign novelty by a profoundly enduring cultural value system? On seeing this work, many Chinese viewers would recall the late Chinese leader, Deng Xiaoping's visit to the Coca-Cola Company's world headquarters in Atlanta, Georgia in 1979 , following the announcement the previous December that Coca-Cola would open a plant in Shanghai. Whatever else it might be, this work is about more than art itself, and, like so much Chinese avant-garde art, that 'aboutness' has a specifically Chinese agenda. Artworld participants can readily convince themselves that this is art that matters owing to its social criticism, whether overt or obscure, thereby satisfying a nostalgia for when Western artworld art might have mattered, and filling at least some of the huge void resulting from its solipsistic practices.

2.

Let us now look a little more closely at art practice in contemporary China in an attempt to grasp some of the issues arising from Chinese artists' dealings with the global artworld, with Chinese tradition, and with art beyond the artworld.

Four basic types of artist work in China. One follows an early twentieth-century Modernist tradition, introduced into China by Chinese artists who studied and worked in Europe-mostly in Paris and Berlin-during the interwar years. Among the leading figures were Lin Fengmian (1900-1991), who destroyed many of his own works during the Cultural Revolution between 1966 and 1976, and Xu Beihong (1895-1953), whose policies as the first president of the Central Academy of Fine Arts following the founding of the People's Republic in 1949 have had an enduring effect. Some contemporary artists continue to work in the diluted Modernist manner, or employ Chinese forms incorporating Western representational conventions associated with this strand of twentieth-century Chinese art. ${ }^{18}$

We have already met some artists of the second type: the Chinese avant-garde. These artists have emerged in only the last twenty-five years. Most were academically trained in traditional art academies, and began an explicit engagement with Western contemporary art as a consequence of the openings promoted and permitted on the initiative of Deng Xiaoping from

\footnotetext{
${ }^{16}$ Tate London, collection database: http://www.tate.org.uk/servlet/ViewWork?workid=589 (accessed September 29, 2011).

17 This work was included in Ai's one person exhibition curated by Karen Smith at the Mary Boone Gallery, New York, March 8 - April 26, 2008.

${ }^{18}$ On Lin, see the website: http://www.linfengmian.net/index.htm (accessed July 27, 2011); On Xu, see $X u$ Beihong in Nanyang (Singapore: Singapore Art Museum, 2008), and the catalogue raisonné, Zidu and Huo Yanwen, Xu Beihong (Beijing: Zhong yan bian chu ban she, 2004) in four volumes (in Mandarin with contents in English, and many illustrations).
} 
1978 onwards. Some of these artists have taken visible social change as their subject. For example, Hai Bo has produced a series of photographic works contrasting past and present appearances. Among them is the poignant 'I Am Chairman Mao's Red Guard' (2000), acquired in 2009 by the J. Paul Getty Museum, Los Angeles. ${ }^{19}$ Hai juxtaposes frontal portrait photographs of the same woman at two points in her life: as a slim youth in her Red Guard uniform clutching her copy of the Quotations from Chairman Mao Tse-Tung (1964), and in middle age wearing a sleeveless, floral printed dress. Most of the leading artists in this field are approaching or are over fifty years of age. Some, like Xu Bing, who left China following the suppression of the Tiananmen Square demonstrations in 1989, have recently returned. Xu Bing was educated at the Central Academy of Fine Arts in Beijing, left China for the United States in 1990 where he received a MacArthur Fellowship in 1999. He was appointed vice-president of his old art school in 2008.

Not all artists of this generation by any means chose to respond directly to Western artworld art, whether Modernist or contemporary. Some Western art museums have been actively acquiring works by Chinese artists who have continued to work explicitly within the conventions of the Chinese pictorial tradition. They constitute my third type of Chinese art. In mainland China, the Cultural Revolution during the decade following 1966, as well as earlier periods of suppression, severely interrupted the transmission of traditional art skills. Some of the finest practitioners moved to Nationalist Taiwan, Hong Kong, Singapore, or beyond. In recent years, though, mainland China has engineered a rapprochement. The career of Liu Guosong, born in 1932, exemplifies this. From Taiwan he moved to Hong Kong in 1971, where he taught for twenty years. Since 1981 he has been visiting mainland China, influencing the revival of traditional painting styles. He was given an exhibition at the Palace Museum, Beijing in 2007, and at the National Art Museum of China, Beijing, in $2011 .{ }^{20}$ Still active, Liu now divides his time between Taoyuan (Taiwan), and Shanghai. Liu is far from alone. The official promotion of traditional art includes not only instruction, principally at the Suzhou Academy of Traditional Chinese Painting, but regular exhibitions at the National Art Museum. In 2011, for instance, the museum held an exhibition not only of Liu's work, but of that of the fifty-eight-year-old Zhou Yibo. ${ }^{21}$ Zhou works within the traditional Chang'an school of painting. He is a professor at the Xi'an University of Architecture and Technology, School of Art, and-perhaps tellingly-vicechairman of the Shaanxi Provincial Committee of Chinese People's Political Consultative Conference. Art produced within the revived and officially sanctioned tradition of ink painting is more likely to be, though is not necessarily, more politically tractable than art that more openly conforms to contemporary Western modes.

The fourth type of Chinese art I identify is art seemingly outside the artworld, whether that of older Modernism, or the global contemporary artworld recently joined by Chinese avantgarde artists, or that of Chinese traditional artists. By this I do not mean any lingering trace of Chinese socialist realism, derived from Stalinist Soviet models, the only sanctioned style in the People's Republic for generations. This survives interestingly in certain arch, commercial design

\footnotetext{
${ }^{19}$ Exhibited in Photography from the New China, Getty Center, Los Angeles, December, 2010 - April, 2011: http://www.getty.edu/art/exhibitions/new_china/ (accessed July 27, 2011) with link to illustration and description.

${ }^{20}$ A Creation Exhibition by Liu Guosong - Looking back at 80, National Art Museum of China, March 21 April 3, 2011: http://211.103.233.9/en/Exhibitions/201102/t20110225_133746.html (accessed July 27, 2011).

${ }^{21}$ Ink Soul at Midnight-Art Exhibition of Zhou Yi Bo, National Art Museum of China, April 5 - April 17, 2011: http://211.103.233.9/en/Exhibitions/201103/t20110328_138326.html (accessed July 27, 2011).
} 
images, such as a recent advertisement for the Apple iPad in which a heroic, smiling tractor driver holds aloft an iPad, ironically evoking the 'Little Red Book' of the Quotations from Chairman Mao Tse-Tung during the Cultural Revolution. ${ }^{22}$ Rather, I mean the extraordinary phenomenon of the cheap copy. Much of the trade takes place via the Web. ${ }^{23}$ It includes derivatives from, and copies of, traditional Chinese paintings-long an artisanal industry in Hong Kong, now also practiced on the mainland. Although cheap oil paintings, many of them copies of well-known Western prototypes, are produced in several Asian countries, and elsewhere in mainland China, the center of the practice is currently Dafen Village, in Shenzhen just north of Hong Kong. ${ }^{24}$ A Hong Kong businessman moved his enterprise there to take advantage of the Shenzhen Special Economic Zone. In Dafen, around 8,000 full-time artists are said to produce something like sixty percent of the world's oil paintings. Some are sold in small galleries locally to foreign visitors who throng there. Many are sold to wholesalers throughout the world. The Internet accounts for yet another segment of the sales, directly or through innumerable intermediaries. The artists are predominantly copyists who have not been able to attend art schools or college, but who have learned their skills mechanically. Some produce their own work, but copying is relatively lucrative compared with other possible options. Zhao Xiaoyong, photographed painting a van Gogh self-portrait in April, 2011, reported that in his career to date he has painted about 70,000 van Gogh copies. ${ }^{25}$ Copies can be ordered to size, and some websites offer helpful mock-up domestic scenes so that customers can decide what size would best fit their circumstances. ${ }^{26}$

From the point of view of aesthetics, even if not from those of anthropology and history, it is all too easy to dismiss this phenomenon. This activity, after all, is taking place outside the artworld. Yet even when considering aesthetics, to dismiss this mass commercial practice would be unwise as we ponder the big questions concerning globalization, its attendant aesthetic homogenization, and relationship to local traditions. In the Blue Book, Ludwig Wittgenstein cites the beam of his reading lamp as having indefinite boundaries, but for all that, clearly existing. ${ }^{27}$

\footnotetext{
${ }^{22}$ Produced in association with Neonpunch of Hong Kong: see 'Neonpunch roundup: All about Apple, iPhones, and iPads', CNNGo website, March 17, 2010: http://www.cnngo.com/explorations/none/neonpunch-roundup-all-about-apple-iphones-and-ipads211201 (accessed July 27, 2011).

${ }^{23}$ See, for example, the hand-made copies of, and derivations from, traditional Chinese ink paintings available through YeahVeryGood.com: see http://yeahverygood.com/Chinese-Painting-c4_p1.html (accessed July 27, 2011).

${ }^{24}$ Copyists are at work in other places in China, too, for instance, Xiamen (Fujian Province), where Tianhong Art \& Craft International Ltd. claims to employ over 400 professional artists who copy paintings for wholesale distribution. 'We are the leading hand-painted wholesaler. We wholesale $100 \%$ handmade oil painting on cavans [sic] with a wide range, include classicalism, impressionist, contemporary, modernism, portrait, still life, abstract, old master, landscape, seascape, moder [sic] decor art etc. We have over 400 full-time talent artists, we creat [sic] original oil painting according to market upcoming trends. We can create a new painting based on customers' photos (old masters' paintings, moder [sic] paintings, photographs or other sources). We can compine two photos into a new style. We can change a painting to fit your colours and more and more': http://www.madeinasia.com/factory-103205/aboutus.html (accessed September 30, 2011).

${ }^{25}$ The Reuters story with photographs of Zhao painting a van Gogh copy by Jason Lee was published widely, for example by 2Space, April 28, 2011. See: http://www.2space.net/news/article/3521261303958410/ (accessed July 27, 2011).

${ }^{26}$ For example, see: http://www.book530.com/ (accessed July 27, 2011).

${ }^{27}$ Ludwig Wittgenstein, Preliminary Studies for the 'Philosophical Investigations' Generally known as the Blue and Brown Books, ed. Rush Rhees, $2^{\text {nd }}$ edition (New York: Harper \& Row, 1960), p. 27.
} 
The four types of art practice I have identified in China-Modernist, avant-garde, traditional, and mass commercial-are like four such lamp beams intersecting. Further, they all have both overt and concealed connections to entrenched practices of emulation, imitation, and copying.

3.

Describing Chinese art in terms of emulation, imitation, and copying is open to misunderstanding. First, in China, visual art has been considered distinct from other broadly expressive forms, such as poetry and calligraphy, only recently, and even then equivocally. Second, emulation, imitation and copying long constituted a range of practices that were-and are-part of how an artist (who might also equally be a poet and calligrapher) ideally aimed to achieve what Craig Clunas describes as the 'perfect balance between the transmission of ancient models and the formation of his own style' thereby assuming a place in 'the great chain of cultural transmission'. ${ }^{28}$ We should beware of thinking of emulation, imitation and copying in China as necessarily unchanging constants essential to Chinese practice, although this is how they are all too frequently seen from the outside. This association has long-standing international as well as local dimensions.

Chinese so-called 'trade' artists have been copying and emulating Western artworks for the Western market since at least the eighteenth century. One of the best known such artists of the first half of the nineteenth century was Guan Qiaochang, known to Westerners as Lam Qua. He had studied in the 1820 s with George Chinnery, the first English painter to settle in China. Lam Qua developed a clientele for portraits among Western merchants and missionaries in Canton, where he and his brother developed mass production techniques. His self-portrait from the 1840 s is in the Peabody Essex Museum, Salem, Massachusetts. ${ }^{29}$ Other artists were identified by the name Lam Qua well after Guan's death in about $1860 .{ }^{30}$ In 2010, the Peabody Essex Museum acquired a copy of Ingres's 1814 Grande odalisque. ${ }^{31}$ It bears the inscription 'Lamqua', but may not be by Guan. It is, though, a nineteenth-century Chinese copy.

Copying, or imitating, works by Western artists is scarcely a new activity. Neither is it exclusively the preserve of artisans who never attended art schools, as in Dafen today. Since at least the 1980s, some orders for copies from entrepreneurs who control the greater part of the market have been filled by teachers and students at various art schools 'moonlighting' for much needed extra income. Furthermore, successful Chinese avant-garde artworld artists have used the services of artisan copyist painters to produce conceptual works, some of which comment directly on the phenomenon of copying Western old masters. Zhou Tiehai's 2004 painting, Palace Woman, substitutes the head of the American cigarette advertizing character, Joe Camel, for that of the odalisque. ${ }^{32}$ Zhou may design his ironic paintings, but they are doubly ironic, for

${ }^{28}$ Craig Clunas, Elegant Debts: The Social Art of Wen Zhengming, 1470-1559 (London: Reaktion Books, 2004), p. 36. Clunas describes the sixteenth-century artist, poet, and calligrapher Wen Zhengming praising his principal calligraphy teacher, Li Yingzhen in these terms.

${ }^{29}$ See Peter C. Perdue, 'Rise and Fall of the Canton Trade System, I, China in the World (1700-1860s): The Narrow World of Artists of the Canton Trade', MIT Visualizing Cultures: http://ocw.mit.edu/ans7870/21f/21f.027/rise_fall_canton_01/cw_essay04.html (accessed July 27, 2011).

${ }^{30}$ See, for example, a photograph by John Thomson from about 1872 in the Powerhouse Museum, Sydney. See: http://eaobjets.wordpress.com/2010/07/10/photo-of-the-day-4/ (accessed July 27, 2011).

${ }^{31}$ Odalisque, oil on canvas, 30.5 x 47 cm., sold at Duke's, Dorchester, UK, Sept. 23, 2010, lot 1397, $£ 20,000$. Its changed color scheme (pink rather than deep blue curtains), and its reversed composition suggest that it was copied from a print, most likely the 1825 lithograph.

32 The painting (airbrushed acrylic on synthetic canvas) is in a private collection, but is illustrated in the online archive of the ShanghART Gallery, Shanghai: 
artisans execute them using airbrush equipment. In 2005, the avant-garde artist, Liu Ding addressed the phenomenon of artisanal non-artworld art production directly. He contrived a performance at the second Guangzhou Triennial in which for four hours thirteen painters hired from Dafen Village painted forty canvases, all the same size: excerpts of varying extent of a single landscape composition. The title of the piece was Samples from the Transition C Products Part 1, evoking their formal bureaucratic designation. ${ }^{33}$ Part 2 consisted in those forty paintings, in gilt frames, exhibited salon style in the L. A. Galerie - Lothar Albrecht, Frankfurt, Germany, and the Fondazione Sandretto Re Rebaudengo, Turin, Italy in 2006. In 2007, the gallery offered individual paintings for sale from the installation. ${ }^{34}$ In this and other contemporary artworld projects exploiting Dafen painters, in the words of Winnie Won Yin Wong: 'we see thus not only versions of post-studio authorship collapsed onto a living readymade, but also a specific slice of China's productive, transitional economy reframed as a transnational object of aesthetic desire'. ${ }^{35}$

This practice of using non-artworld Dafen painters within the artworld has moved beyond China itself. For his MFA thesis project at the School of the Museum of Fine Arts, Boston and Tufts University, John C. Gonzalez ordered self-portraits by fifty-two unidentified painters at one Dafen workshop. He exhibited them together with a photograph of the head of the company holding Gonzalez's own painted self-portrait, which he had sent to Dafen. Gonzales gave the installation the title Self-Portrait Project (2009-11). ${ }^{36}$ What is happening in such a work? In a recent interview, Gonzalez responded:

[M]y wife has really interesting observations. She said something that made a lot of sense, 'Well you know honey, what you are doing, you are always trying to give a voice to the underdog. That's what you're trying to do.' I thought about that, 'Yeah, I kind of am.' Why do I want to do that? What does it mean for me to give a voice to the underdog? But at the same time I'm not really giving a voice to the underdog, I'm giving my interpretation. ${ }^{37}$

This catches the equivocal nature of Gonzalez's project-perhaps of any project that places a relatively privileged artworld insider in an economic relationship with disadvantaged pieceworkers.

A further complication arises from the recent adoption by the most prestigious, though also cupidous, institutional members of the artworld-the leading auction houses-of sales methods previously confined to the marketing of non-artworld art. An example is ArtLink@Sotheby's, the auction house's online marketing tool for work by emerging contemporary artists. Six works by

http://www.shanghartgallery.com/galleryarchive/simpleWork.htm?workld=4272 (accessed July 27, 2011).

${ }^{33}$ Ulrike Münter, 'Heimspiel', Chinesische Gegewartskunst, Aug. 9, 2009, with two illustrations: http://www.chinesische-gegenwartskunst.de/pages/ausstellungen/heimspiel-shcontemporary.php (accessed July 27, 2011).

${ }^{34}$ See the L.A. Galerie - Lothar Albrecht website: http://lagallery-frankfurt.de/DinglnvitationE.pdf (accessed July 27, 2011), and http://www.artnet.com/galleries/ArtFairs.asp?gid=636\&cid=123643 (accessed July 27, 2011).

${ }^{35}$ Winnie Won Yin Wong, 'Framed Authors: Photography and Conceptual Art from Dafen Village', Yishu: Journal of Contemporary Chinese Art 7, 4, 2008, p. 38.

${ }^{36}$ Exhibited at Lufthansa Studios, Dorchester, Massachusetts, 2011.

${ }^{37}$ Andrea Sherrill Evans, 'John C. Gonzalez', Temporary Land Bridge: A Blog of Artist Interviews, Studio \& Gallery Visits, May 16, 2011: http://temporarylandbridge.com/ (accessed June 8, 2011). Winnie Won Yin Wong kindly drew my attention to this work by Gonzalez. 
Julie An, a Korean artist who uses photography, appear on ArtLink@Sotheby's. ${ }^{38}$ In her work, An clearly responds to the artwork role-playing works of the long-established artists Cindy Sherman and Morimura Yasumasa. If we select the ArtLink page for An's Odalisque, we learn that it exists in an edition of three, and that its status is 'sold. ${ }^{39}$ No matter, though, for we can click on the words 'Buy a print of this artwork.' This opens a link to Art2Go: 'Buy High-End Reproductions'. ${ }^{40}$ Just as on the non-artworld commercial reproduction sites, you can select the print size of your choice. Once again, a sofa helpfully gives you a sense of scale. One has to think quite hard before realizing that it is actually a limitlessly producible reproduction that is on offer. The one distinction between the reproductions from Sotheby's Art2Go and from Dafen Village is that the former are photographic prints whereas the latter are hand-painted.

Do all these overlaps and similarities suggest that distinctions among avant-garde, traditional, and assembly-line mass commercial art in China are breaking down, and also between artworld art and non-artworld art more broadly? In terms of production, this would not seem to be the case. There are still social distinctions between the art of artists who are educated in art schools, so certified as artists, and artists who work predominantly as artisans outside this system. Consumption, though, is another matter. Distinction depends largely on encounter with actual works in their unique, or at least peculiar, physicality. When encounter is virtual, with electronic tokens of the artwork imaginable in any convenient size in relation to a sofa, that distinction is blurred. The World Wide Web has not created this phenomenon on its own, but it has certainly accelerated and strengthened the blurring effect.

All four types of art being produced in China share a complex of characteristics: imitation, emulation, and copying. Examining how this is manifested in a wide variety of ways is vital to understanding what is at stake aesthetically in Chinese art in relation to the supposed globalization of values.

While copying is not an exclusively Chinese phenomenon-copyists work in Vietnam, Thailand, and elsewhere-copying Western art in China goes back to the eighteenth century, and, as we have seen, was developed on a large workshop scale by those artists operating in Canton under the name of Lam Qua from the 1820s onwards. Much Chinese traditional brush painting practice centered on the imitation and emulation by aspirant or even highly accomplished artists of works by their revered predecessors, constituting what Xu Bing has termed a conversation between generations. Chinese avant-garde artists, many of whom have turned their attention to the art of the West-both early European modernism emulated by their own predecessors in the first half of the twentieth century, and predominantly American high modernism of the 1950s, '60s, and beyond-also emulate Chinese traditional art. Indeed, they are under considerable unspoken pressure to do so, both in China, and in the West. Much Chinese avant-garde art making occurs as instances of the fulfillment of just this unarticulated expectation. The consequence is double-edged: without denying that the results can be extremely rewarding in every sense, there are inhibitory consequences to conforming-however unwittingly - to a stereotype. Artworld institutions no less than non-artworld commercial art enterprises foster this phenomenon, termed by Winnie Won Yin Wong 'staging'. The next section examines how this works in detail by addressing two recent exhibitions.

4.

${ }^{38}$ See: http://www.artlink.com/iya/artist.asp?aid=598 (accessed July 27, 2011).

${ }^{39}$ See: http://www.artlink.com/iya/gallery.asp?wid=29 (accessed July 27, 2011).

${ }^{40}$ See: http://www.artlink.com/Ar2Go/sizes.asp?wid=29 (accessed July 27, 2011). 
Between November, 2010 and February, 2011, the Museum of Fine Arts, Boston (MFA) held an ambitious and striking exhibition, Fresh Ink: Ten Takes on Chinese Tradition. The museum website describes it as follows:

In this groundbreaking exhibition, contemporary Chinese ink painters engage in dialogue with classical artworks from China's past. At the core of this exhibition's concept is an artistin-residency program. Leading artists from China and the Chinese diaspora have come to Boston to study the MFA's superb collection of Chinese art, allowing them to create new works in direct response to the Museum's permanent collection. In the exhibition, the new works and the masterpieces they refer to will be juxtaposed in the new Gund Gallery-the ancient will historicize the contemporary, while the contemporary will revitalize the ancient. $^{41}$

In 2006, ten artists, all but one directly or indirectly from China, took up residencies at the MFA. Each was charged specifically with exploring the museum's fine collection of Chinese art, choosing a work from it, and then producing new work in response. This project was the brainchild of the MFA's curator of Chinese art, Hao Sheng. Hao was one of the new cohort of accomplished young art museum curators featured in an article in the New York Times in March, $2010{ }^{42}$ Hao is a native of Shanghai, but was educated at the College of Wooster, Ohio, where he changed his field of study from physics to studio arts and art history. He then apprenticed to a master ceramicist in Japan for three years before returning to the USA to begin doctoral studies in Chinese art history at Harvard University. Under 40 years old, he was appointed to the curatorship at the MFA even before completing his dissertation.

All but one of the ten artists for whom Hao arranged residencies chose Chinese objects with which to enter into dialogues. Six of the ten chose painted handscrolls dating from between the eleventh and the fifteenth centuries: Liu Xiadong, Zeng Xiaojun, Li Huayi, Qiu Ting, Li Jin, and the only woman among the ten, Yu Hong. One-Qin Feng-chose a late eleventh to early tenthcentury BC inscribed bronze ceremonial wine vessel. Liu Dan chose a Ying limestone scholar's rock collected in the seventeenth-century; while Xu Bing selected the only twentieth-century Chinese work - the woodblock printed book, the Mustard Seed Garden Manual of Painting, published in 1923-25, but initially published in 1679.

The only surprise was the choice of Jackson Pollock's 1949 painting in oil, enamel, and aluminum paint on canvas, Number 10. Long and narrow, it was displayed horizontally, like an unrolled Chinese handscroll, in the same orientation in which it had originally been conceived and painted in Pollock's then innovative drip manner. This was the choice of Arnold Chang, who, perhaps not coincidentally, was born and raised in New York City. We should be surprised that this glaring exception should be a surprise. Hao's assumption in curating the project was that his guests would-indeed should-work with Chinese material. Only Chang transgressed, producing and exhibiting Secluded Valley in the Cold Mountains in response to the Pollock. It is an ink-onpaper handscroll resembling a traditional Chinese landscape painting. As Joseph Scheier-Dolberg expresses it in the exhibition catalogue, 'Chang is using Number 10 to teach us how to look at Chinese paintings, urging us to engage in the intensive line-by-line exploration that marked his own education and defines his passion for literati landscape ${ }^{43}$. What looks like a possibly

\footnotetext{
${ }^{41}$ See: http://www.mfa.org/exhibitions/fresh-ink (accessed July 27, 2011).

${ }^{42}$ Carol Vogel, 'The New Guard of Curators Steps Up', New York Times, March 13, 2010.

${ }^{43}$ Hao Sheng, Fresh Ink: Ten Takes on Chinese Tradition, with essays by Joseph Scheier-Dolberg and Yan Yang (Boston: Museum of Fine Arts, 2010), p. 55.
} 
cosmopolitan choice turns out-however interestingly-to be no less local in its focus than that of the other nine artists in the exhibition.

There is no escape, after all, from a relentless staging of, emulation of, and dialogue with, a purely local past conceived of not as providing material to be equaled and excelled in a competition with predecessors while striving for originality and achieving progress, as the modern Western ideology of art making has it. Rather, with their contributions these contemporary artists add to an incrementally formed permanent present of works they can never, in any sense, supersede. This is so even when they represent unmistakable contemporaneity, even American-specifically Bostonian-contemporaneity, as in Li Jin's Reminiscence to Antiquity, 1-7 (ink and color on paper, 21 album leaves on seven hanging scrolls) in which a figure wears a Boston Red Sox baseball cap. Yet even here, staging emulation takes precedence over cultural translation.

In his own work of copying for the MFA exhibition, Mustard Seed Garden Landscape Scroll (2008-10), Xu Bing deconstructs rather than simply conforms to the artifice and conventions of traditional Chinese painting. When it was first published in 1679, the Mustard Seed Garden Manual of Painting made widely available through woodblock printing the particular manners of representing individual motifs associated with great painters. These were the ways of representing human figures, trees, mountains, and all other constituents of landscape paintings that artists were to copy and incorporate fittingly into their own works. Because the manual was continuously in print, its codified pictorial formulae held sway for some three hundred years. Xu reproduced individual motifs, arranged them in his own long handscroll landscape composition without concealing the joins, or observing the decorum that governed the proper choice and combination of motifs. What is more, his handscroll is not painted, but rather printed from woodblocks, like the manual, thereby transgressing propriety yet further. Like $A$ Book from the $S k y$, with its subtly outrageous 'false' and literally meaningless host of characters, Xu overturns Chinese conventions even while seeming to observe them by means of producing an artwork that flies in the face of traditional taste while using its very ingredients. Yet like all worlds turned upside down, this apparently subversive gesture is ultimately confirmatory of traditional values, for it overturns merely, rather than proposes an alternative.

One can say the same of another project by Xu Bing. It, too, is a staging of artists', curators' and critics' most profound expectations about the imitative and emulative character of Chinese art, whether Modernist, avant-garde, traditional, or mass commercial. Those who entered the British Museum between May 12 and July 10, 2011, and turned right immediately towards Room 3, saw against the deep blue background of the gallery walls, a freestanding, sixteen-foothigh screen supporting a Chinese landscape. ${ }^{44}$ The image of steeply receding mountains, forest, and river had the appearance of a monochrome brush-and-ink drawing, a monumental hanging scroll. The surface was backlit, so the landscape seemed painted not on the side facing the viewer, but on the reverse of the translucent screen. On the left was a smaller hanging scroll with an identical landscape composition. A label stated that the scholar-artist Wang Shimin had

\footnotetext{
${ }^{44}$ The account that follows is adapted from my review of $X u$ Bing, Background Story 7 in artUS (forthcoming). See also the press release at http://www.britishmuseum.org/the_museum/news_and_press/press_releases/2011/xu_bing_at_the_bri tish_museum.aspx (accessed July 10, 2011). I am also grateful to Neil MacGregor (director of the British Museum), and the curator responsible for the exhibition, Jan Stuart (keeper of the Department of Asia, British Museum) for comments expressed in email correspondence.
} 
painted it in $1654 .{ }^{45}$ Why had Xu Bing reproduced it? Was he no more than staging the Chinese propensity to imitate, emulate, or even simply copy?

Those who ventured round the back discovered the artifice. The light-box, open at the rear, was edged with fluorescent tubes. A jumble of branches, leaves, twigs, and teased hemp fiber was stuck to the screen with Scotch tape. Similar, locally gathered material, together with stubs of colored chalk and rolls of tape, littered the inside of the bottom of the light-box. On returning to the front, the viewer could disbelievingly correlate the shriveled vegetation stuck to the screen with the exquisite image on the front. Xu had recreated Wang's landscape not in ink, but with the shadows cast by vegetable fragments stuck to the back of frosted acrylic. Where twigs and leaves stood out slightly from the surface, the shadows lost depth, darkness, and clarity. Their penumbrae imitated the delicate wash of diluted ink. The illusion was intense. Xu had not merely engaged in a standard form of copying or even of emulation. Rather, he had created a contemporary trompe l'oeil that examines the conditions of representation in the Chinese tradition, yet participates fully in contemporary Western self-reflectivity.

This is a work of multiple resonances. What are Wang's ink and paper but products derived from the vegetable world, like Xu's, only more thoroughly processed and refined? Not before viewers had entered the zone of direct light behind the screen were they literally enlightened. In front of it, the viewer occupied the Chinese equivalent of Plato's Cave, contemplating the illusion of a shadow world taken to be a real painted representation; yet behind it one could see that this apparent reality comprised shriveled remnants of actuality.

Background Story 7 was the latest in Xu's series of scroll recreations using light-and-shadow boxes, his first in vertical format. The project conformed to, yet extended, a peculiarly Chinese procedure of imitation, emulation, and conversation with older art. In his 1654 hanging scroll landscape, Wang Shimin had imitated, emulated, and conversed with scroll paintings by Huang Gongwang, his predecessor by three hundred years. Vice-president of the China Central Academy of Fine Arts, Beijing, $\mathrm{Xu}$ is a government official, as was Wang over three hundred years previously. As such, $\mathrm{Xu}$ is surely aware that the detritus of reality only finds its representational perfection in the contrivance of shadows to maintain illusions. In Background Story 7, as in earlier works in this series executed in China, Korea, Germany, and the USA, Xu exposed the illusion of perfection to be the skillfully improvised manipulation of messy reality. Thus is the life in art.

5. I have only been able to look at a few examples of the staging of Chineseness in some Chinese avant-garde art practice, yet it occurs in all four types of art practice current in China. I want to be clear, though, that current Chinese art practice cannot simply be reduced to matters of staging Chineseness or staging emulation. Overturning, parodying, contesting, revising, and translating various conventions of Chinese art and expectations about it are among the practices open to contemporary Chinese artists, though none of these necessarily precludes such

\footnotetext{
${ }^{45}$ Wang Shimin (1592-1680), Hanging Scroll: Mountain with River, Bridge, and Building, ink on paper, 1960,1008,0.1, British Museum, London; collection database entry: http://www.britishmuseum.org/research/search_the_collection_database/search_object_details.aspx?cu rrentpage $=1 \&$ titlesubject=on\&toadbc $=$ ad\&objectid $=269752 \&$ orig $=\% 2$ fresearch\%2fsearch_the_collection_ database. aspx\&partid=1\&searchtext=Wang+Shimin\&fromadbc=ad\&numpages=10 (accessed September 29, 2011).
} 
staging. ${ }^{46}$ Indeed, staging of the kind I have tried to identify is absent only infrequently. What are the larger aesthetic consequences of this staging of Chineseness in relation to the production and reception of Chinese art in the wider world? While a partly homogenized, cosmopolitan artworld continues to function, churning huge sums of money and sending artworld art to new centers of vastly unevenly distributed wealth, such as China, it does so in part on the basis of misapprehension after misapprehension, as participants of all kinds tend to see what they want to see in the work, and nothing more. While Chinese avant-garde art functions perfectly well by conforming to Western artworld standards-physically, conceptually, thematically -it also engages with forms and issues peculiar to its local circumstances that can remain opaque to cultural outsiders. Meanwhile, and more obviously, revived traditional art in China and elsewhere continues to require explicit cultural translation if it is to travel at all. Few concerned with globalized contemporary artworld art pay revived traditional Chinese art any mind, unless it is the subject of voracious expropriation on artworld terms. All four types of art produced today in China- Modernist, avant-garde, traditional, and mass commercial-are shaped at their most fundamental level by a set of expectations shared by artists and all other concerned people in the artworld and beyond regarding the requirement of Chinese art to stage Chineseness in ways both predictable and unpredictable. This is the fundamental role that most participants in the artworld and the larger commercial world expect of Chinese art of whatever type.

In the light of this observation, I return to the fundamental question posed earlier: Are we to have a single, varied but coherent governing set of values-including aesthetic values-in the artworld? While we should not underestimate the power of financial interests to push the artworld in a globalizing, homogenizing direction, reinforcing stereotypes such as the Chinese staging of imitation and emulation, I see a proliferation of variety of values as unavoidable while contemporary artworld practitioners continue to introduce local concerns both wittingly and unwittingly. I also see the self-claimed high status of artworld art being progressively challenged by the vitality worldwide of non-artworld art, itself embodying a huge variety of valuesincluding aesthetic values. While some of these are resistant to Western homogenization, others conform to it. In the light of this realization, I ask a final question: Can there be a successful aesthetic resistance to the effects of the global artworld and non-artworld, mass commercial art markets? The short answer in an era of proliferating, ruthless hypercapitalism is no. Yet insofar as aesthetics is politics by other means, there are urgent concerns to which philosophers and other scholars can give voice: the conditions of employment of artisan artists, and the persecution of artworld artists, in China and elsewhere. In the meantime, peopleartists - create surprises. Some, at least, will always make aesthetically challenging, provocative, and even inspiring work.

\footnotetext{
${ }^{46}$ I owe this point to John Lysaker.
} 